\author{
N. SAVCHENKO (Candidate of Technical Sciences) \\ State Institution of Higher Education "Donetsk National Technical University" \\ natali_a_savchenko@ukr.net
}

\title{
EQUALIZING BUILDING LOAD DIAGRAM BY THE METHOD OF RANDOM COMPONENT COMPENSATION WHEN CONNECTING A GROUP OF KINETIC ENERGY STORAGES TO POWER SUPPLY SYSTEM
}

Abstract. The article presents the results of a theoretical study of the process of regulating the load diagram while compensating its random component by connecting a group of kinetic energy storages devices to the power supply system of the administrative building. Daily load diagrams of the administrative building are presented in the form of an additive model. The definition of the law of load distribution is validated. The structure of group of kinetic power storages connecting to the power supply system of administrative building has been developed to compensate the random component of the load diagram. A method of load diagrams equalizing by random component compensating is proposed. Application of the proposed method of load equalizing will allow controlling effectively the capacity of load in the building's internal power supply system.

Key words: power supply system, kinetic energy storage (KES), electric load diagram (ELD), additive model, load regulation method.

Introduction

Currently, one of the main methods for regulating the load in low-voltage networks with a voltage of $0,4 \mathrm{kV}$ is to attract and stimulate consumers to align their load diagrams, which entails improving the quality and reliability of the power supply system. The essence of the method is the introduction of various drives and batteries in the power supply systems of consumers and the use of these consumers as load regulators in the power system [1].

The desire to improve environmental friendliness and at the same time longevity of energy storage for non-energyintensive consumers led to the further development of mechanical storage, namely kinetic energy storage.

There are developments on the use of CES in autonomous power supply systems of buildings in conjunction with alternative energy sources. Such systems can work both autonomously and in parallel with the network [2,3,4,5].

The use of KES in such power supply systems is mainly aimed at controlling the load conditions - discharge of the drive during peak load and charging at night (alignment of day and night load diagrams), which is an important factor in increasing the reliability of power supply system's [6] .

Despite the large number of developments on the use of KES in power supply systems as an energy storage device, this topic has not been fully studied. There are still a lot of possibilities and functions that can be assigned to KES in power supply systems of various objects, one of which is the compensation of a random component of the load diagram in order to equalize it.

Purpose of the study

Goal of the work is an improvement of the load regulation method by isolating a random component and compensating for it by connecting a group of kinetic energy storage devices to the power supply system of the office building.

Analysis of the characteristics of the consumer ELD (administrative building).

The most informative for analysis are daily load diagrams.

The dynamics of the daily power consumption of the consumer is shown in Fig. 1.

The load graphs have a large number of different characteristics and indicators used for analysis in each case.

Analysis of the consumer ELD, which is the administrative building, is carried out in order to determine the nature of the load and the law of its distribution, for further selection of the method of equalizing the ELD.

The main characteristics of the consumer ELD are [7,8,9]:

- effective load $P_{E}$;

- average load $P_{S}$;

- load dispersion $D_{P}$

- form factor $K_{F}$;

- heating coefficient of conductors $K_{N}$ (maximum);

- coefficient of unevenness $\alpha$;

- fill factor $\beta$;

- maximum load control range $\triangle P \max$;

- half-peak load control range $\Delta P_{s p}$. 


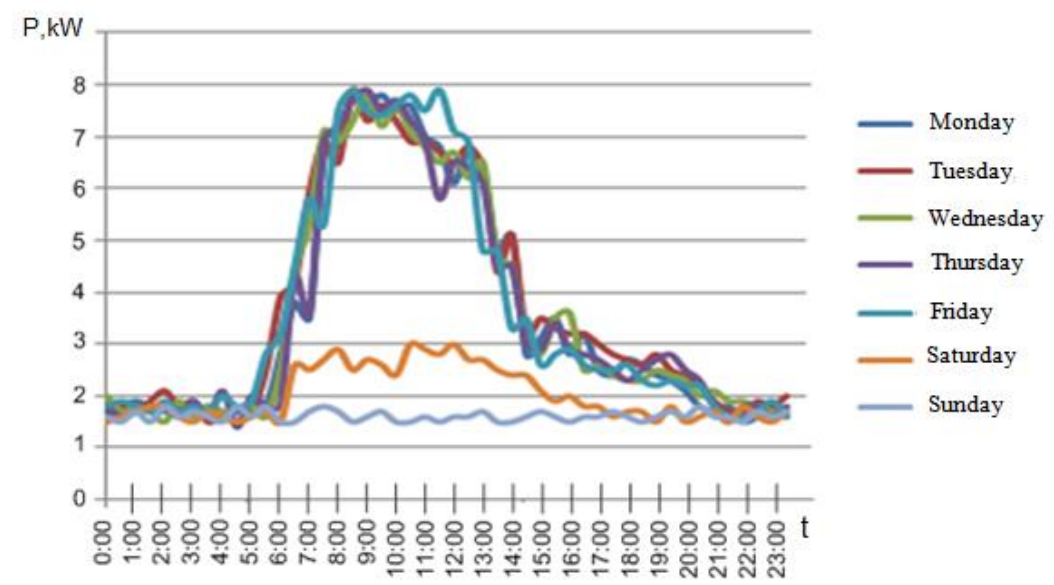

Figure1 - Consumer load daily graphs

The given system of analytical characteristics gives an idea of which part of the ELD needs to be regulated. In this case, it is advisable to perform the calculation only for working days.

The results obtained for the consumer ELD considered in Fig. 1 are shown in Table 1.

Table 1 - Characteristics of the consumer ELD

\begin{tabular}{|c|c|c|c|c|c|}
\hline $\begin{array}{c}\text { Characteristics } \\
\text { ELD }\end{array}$ & \multicolumn{5}{|c|}{ Weekdays } \\
\cline { 2 - 6 } & Monday & Tuesday & Wednesday & Thursday & Friday \\
\hline$P_{S}, \mathrm{~kW}$ & 3,54 & 3,69 & 3,56 & 3,53 & 3,61 \\
\hline$P_{E}, \mathrm{~kW}$ & 4,16 & 4,25 & 4,16 & 4,13 & 4,24 \\
\hline$D_{P}, \mathrm{~kW}$ & 4,77 & 4,45 & 4,63 & 4,60 & 4,95 \\
\hline$K_{F}$ & 1,175 & 1,152 & 1,169 & 1,170 & 1,175 \\
\hline$K_{N}$ & 0,276 & 0,246 & 0,268 & 0,268 & 0,275 \\
\hline$\alpha$ & 0,19 & 0,19 & 0,19 & 0,18 & 0,20 \\
\hline$\beta$ & 0,45 & 0,47 & 0,46 & 0,45 & 0,46 \\
\hline$P_{\max }, \mathrm{kW}$ & 7,8 & 7,9 & 7,8 & 7,9 & 7,9 \\
\hline$P_{\min }, \mathrm{kW}$ & 1,5 & 1,5 & 1,5 & 1,4 & 1,6 \\
\hline$\Delta P_{\max }, \mathrm{kW}$ & 4,65 & 4,70 & 4,65 & 4,65 & 4,65 \\
\hline$\Delta P_{s p}, \mathrm{~kW}$ & 3,15 & 3,20 & 3,15 & 3,25 & 3,25 \\
\hline
\end{tabular}

An important stage of the study is the determination of the law of load distribution, namely, the trending and random component of the ELD.

An analysis of the data obtained in Table 1 allows us to conclude that, in general, ELDs on working days have almost identical analytical characteristics with small deviations, which indicates the predictability of the trend component. At the same time, the random component of the ELD has a slight fluctuation.

The process of changing the load over time is mathematically most fully reflected in the concept of a nonstationary random process. The load at each moment of time is a random variable whose distribution law depends on time [10].

Determination of the law of load distribution of the ELD.

The ELD of the building under study is an unsteady random process (Fig. 1). Therefore, the per diem ELD can be represented as an additive model [7,8,11]:

$P(t)=P_{T}(t)+P_{R}(t)$,

where $P_{T}(t)$ - the trend component of the daily ELD, which is defined as the average over an interval of a given duration $\theta$ with a variable starting point $\mathrm{t}[12]$ :

$P_{T}(t)=P_{C}(t, \theta)=\frac{1}{\theta} \int_{t}^{t+\theta} P(t) d t$,

$P_{R}(t)$ - random component of the consumer's ELD, which is defined as the difference between the actual power of the ELD and its trend component [11]:

$P_{R}(t)=P(t)-P_{T}(t)$. 
Analysis of the daily consumer ELD shows that the differences in the effective and average electrical loads at the 30minute moving averaging intervals do not exceed $1 \%$, therefore, when modeling electrical loads, the following assumption can be made:

$P_{T}(t)=P_{S}(t, \theta) \approx P_{E}(t, \theta)$.

Consider the modeling of the ELD using the example shown in Fig.2.

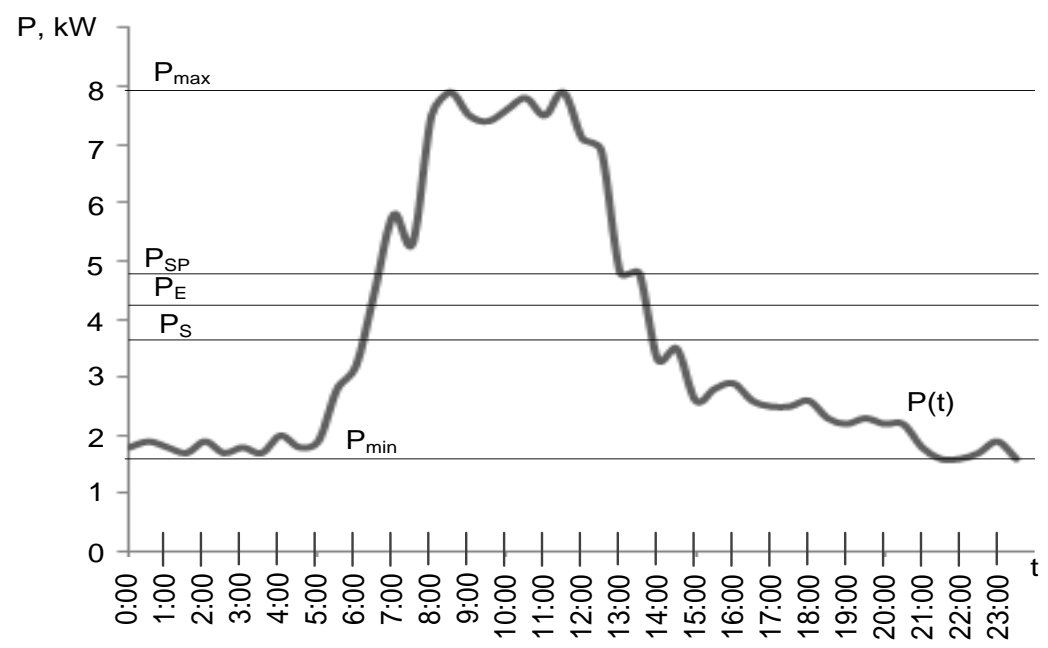

a)

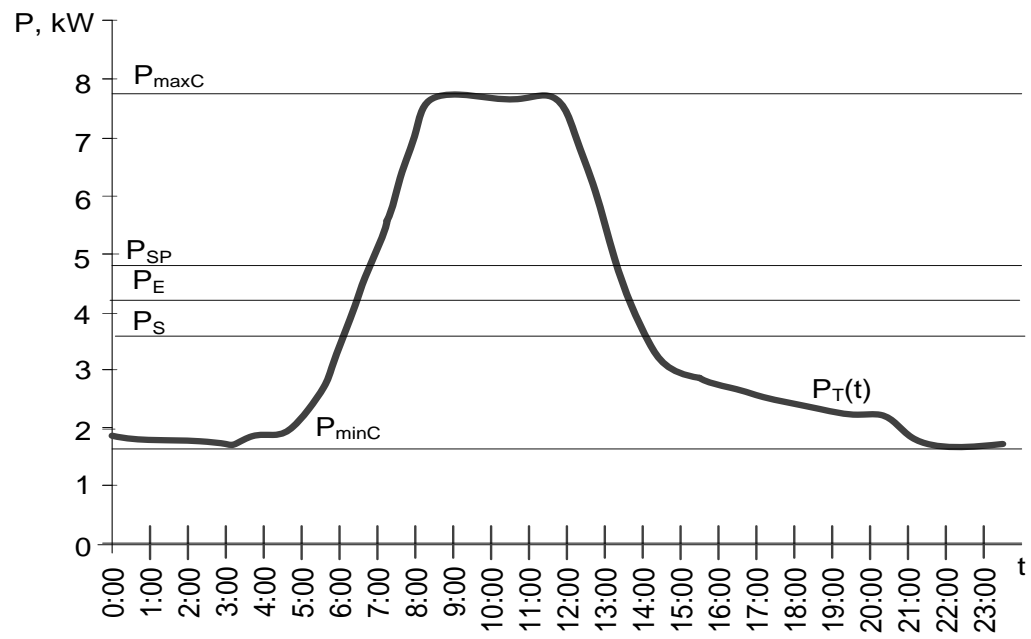

b)

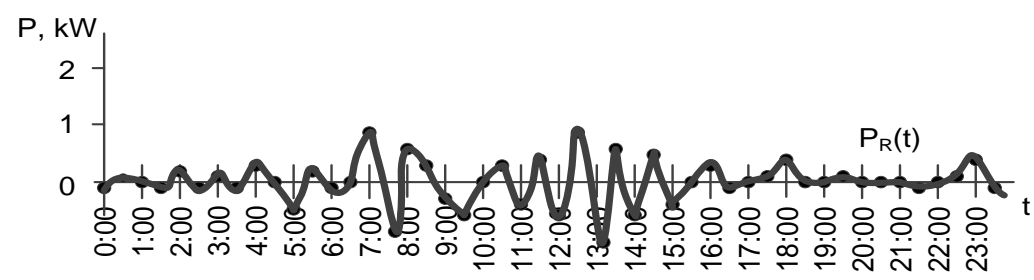

c)

Figure 2 - Consumer ELD (Friday): a) initial ELD P (t); b) rend component of the ELD $P_{T}(t)$; $\left.c\right)$ random component of the ELD $P_{R}(t)$

The shape of the trend component of the consumer ELD practically repeats the original ELD and is determined by the operation mode of individual groups of power receivers. The study of the operating modes of these groups allows us to 
conclude that they are established due to the prevailing consumer work diagram. Also, with a certain degree of idealization, the work of these groups of power receivers can be considered independent, and then, in accordance with the central limit theorem, from probability theory, the law of load distribution for each moment in the stationary interval can be considered close to normal. The assumption that the process is stationary makes it possible to simplify the solution of the problem posed - the study of the process can be replaced by the study of a random variable [10].

The random component of the ELD has characteristic time zones with a minimum load and with a maximum load. For a detailed analysis of the random component, it is necessary to determine the law of its distribution.

Let us verify the assumption of the normal law of distribution of the random component of the ELD $P_{R}(t)$ by Pearson's criterion $\chi^{2}$ (Chi square).

The coordinates of the random component of the $\mathrm{P}_{\mathrm{R}}(\mathrm{t})$ ELD is the random variable e $P_{R}$ with zero mean and non-zero dispersion.

Pearson's $\chi 2$ criterion is a nonparametric method that allows you to assess the significance of the differences between the actual (identified as a result of the study) number of outcomes or qualitative characteristics of the sample falling into each category and the theoretical amount that can be expected in the studied groups if null hypothesis [13 ].

In Fig. 3 shows a histogram of the distribution of the random component of the $P_{R}(t)$ ELD, shown in Fig.2.

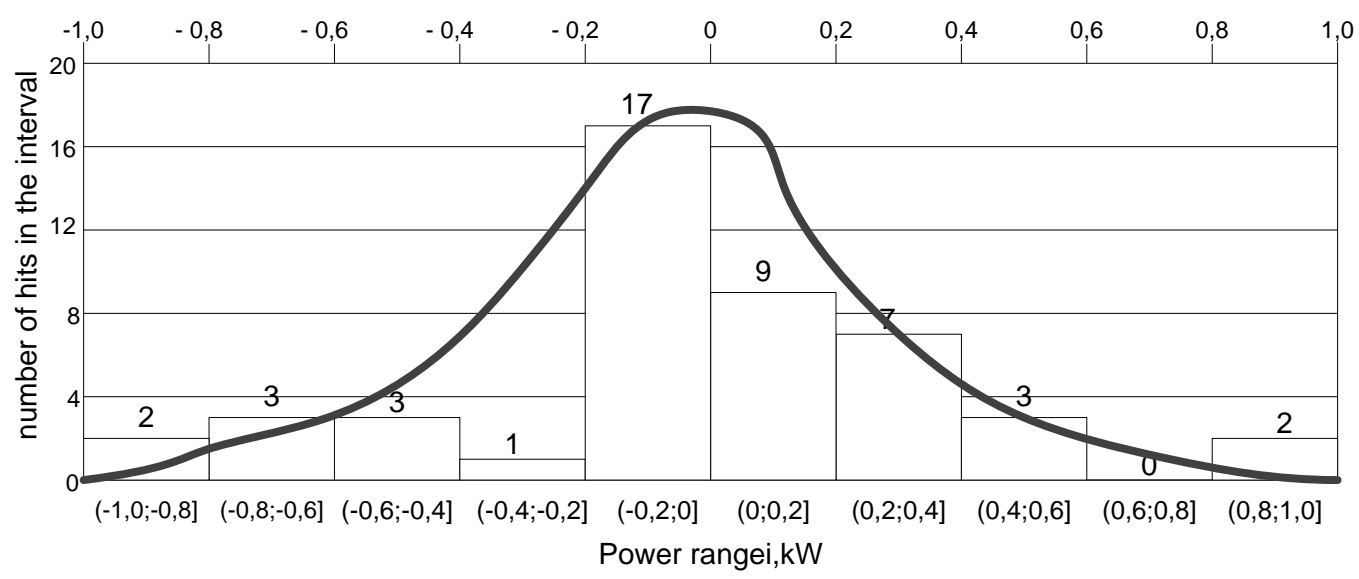

Figure 3 - Histogram of the distribution of a random variable of $P_{R}$ per day

The results of verification according to the Pearson criterion $\chi 2$ of the consistency of the experimental and theoretical (normal) laws of distribution of a random variable $P_{R}$ for the period under consideration are given in Table 2 and fully confirm the existence of a normal law of distribution of the random component of the ELD.

Table 2 - Numerical characteristics of the random variable $P_{R}$ and the results of the consistency check by the Pearson criterion

\begin{tabular}{|c|l|l|l|l|}
\hline Dispersion $D_{P}, \mathrm{~kW}^{2}$ & $\begin{array}{l}\text { Standard } \\
\text { deviation } \\
\sigma_{p}, \mathrm{~kW}\end{array}$ & $\begin{array}{l}\text { Pirson criterion value } \\
\chi^{2}\end{array}$ & $\begin{array}{l}\text { Conclusion of hypothesis } \\
\text { confirmation }\end{array}$ \\
\cline { 3 - 4 } & 2,23 & estmated & critical & \\
\hline 4,95 & 7,32 & 11,1 & is confirmed \\
\hline
\end{tabular}

Studies have shown that the ELD and its components have the normal law of load distribution. The random component of the LES has a small power spread in magnitude and in the case of its compensation, a smoothed ELD will be obtained as shown in Fig. 2 (b), which can also be equalized in the future.

Compensation of the random component of the ELD can be realized by connecting a small power within the range of 1-2 $\mathrm{kW}$ to the power supply system of the building of the KES group, which will make it possible to regulate (equalize) the load diagram of the building during the day with low material costs and high environmental friendliness.

The structure of the model of the power supply system of the building.

A simplified structural diagram of the model of the building's power supply system, taking into account the model of energy transmission, conversion and distribution devices, is shown in Fig. 4.

The operation of the circuit shown in Fig. 4 is carried out as follows: in the case of an accidental slight fluctuation in the load of a building, the magnitude of which is monitored by a load sensor (CT) installed on the building's supply line, one of the KES is automatically discharged, and the second is in energy storage mode, the next period of load fluctuation is discharged by the second KES, and the first is either in energy storage mode or in recharge mode. KES operating modes in the building are controlled by a control unit (MCU) according to a predetermined algorithm by acting on frequency converters (FC) and putting the inverter in the generation mode synchronously with the network to compensate for the 
random component of the ELD.

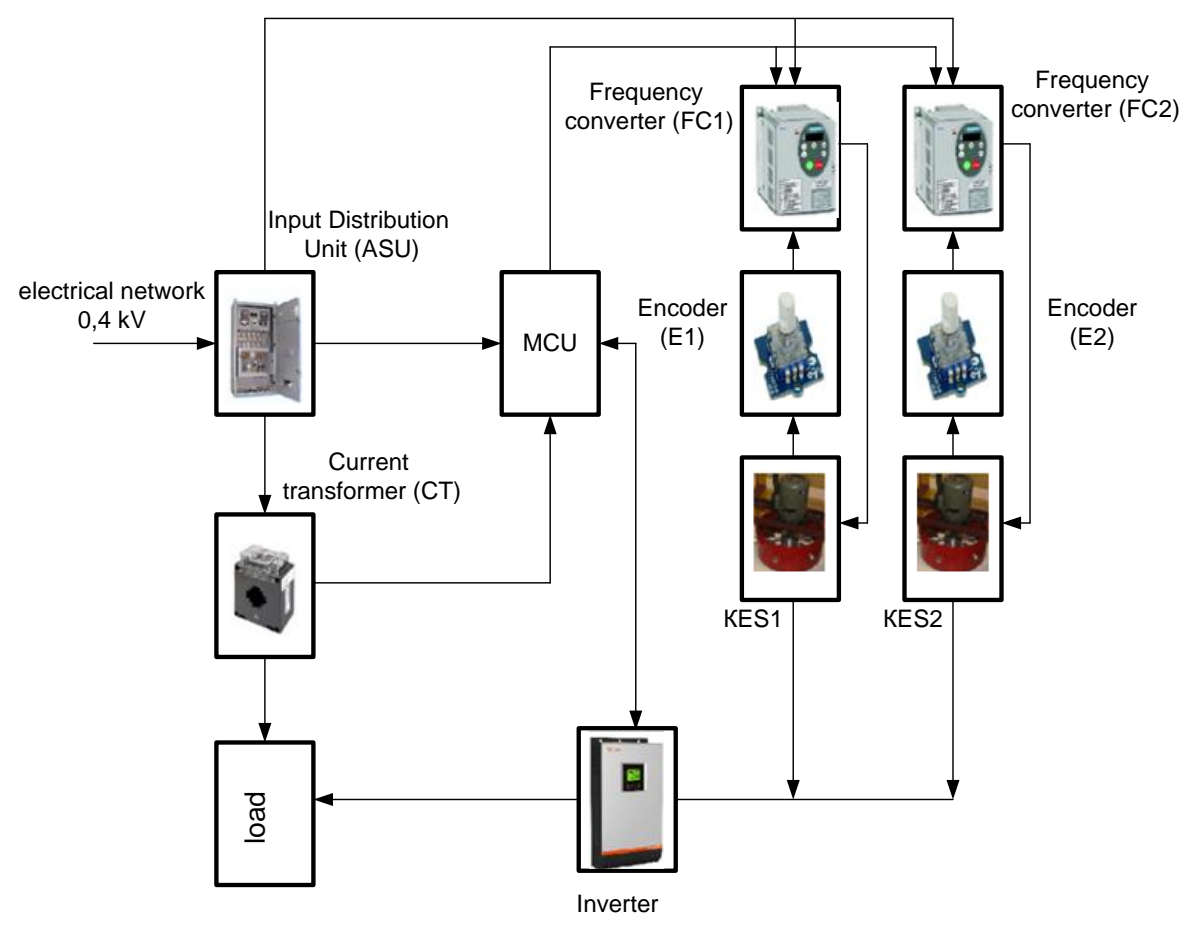

Figure 4 - Structural diagram of a model of a building's power supply system

The mathematical model of the compensation process for the random component of the LEG has the form:

$$
P_{\sum E L D}(t)=\left\{\begin{array}{l}
\text { at } P_{N i}(t) \geq P_{N}(t)+P_{R i}(t), \\
P_{E L D}(t)=P_{N}(t)+P_{K E S 1}(t) . \\
\text { at } P_{N(i+1)}(t) \geq P_{N}(t)+P_{R(i+1)}(t), \\
P_{E L D}(t)=P_{N}(t)+P_{K E S 2}(t) . \\
\text { at } P_{R}(t)=0, P_{E L D}(t)=P_{N}(t) .
\end{array}\right.
$$

where $P_{N}(t)$ - load of the consumer (building);

$P_{R}(t)$ - random component of the consumer ELD;

$P_{K E S 1}(t), P_{K E S 2}(t),-$ compensation power KES1 and KES2, respectively.

In the developed structure of the model of the building's power supply system, a group of drives is used, consisting of two parallel connected KES. The advantage of such a system is scalability, that is, if it is necessary to increase power to compensate for the random component of the ELD, it is possible to connect additional groups of drives.

\section{Conclusions}

1. The analysis of the load curves of a real building based on the additive model confirms the hypothesis of a normal distribution of both the trend and the random component of the electric load graph. The application of this analysis method for buildings of the same type for their intended purpose simplifies the process of determining the load control method and can be automated.

2. Further development of the method of internal regulation of the consumer load by compensating for the random component of the load diagram is proposed, which allows to obtain a smoother and more uniform diagram of the electric load.

3. The structure of the model of the building's power supply system was developed to implement the method of internal load regulation by compensating for the random component of the load diagram. The developed model is described mathematically, which will determine the technical parameters of the devices used in the structure of the model, and their operation algorithm.

4. The application of the studies will improve the reliability of the internal power supply system of the building and the efficiency of load regulation with low material costs and high environmental friendliness. 


\section{REFERENCES}

[1] Shevchenko, S. Yu., Savchenko, N. A., Tretjak, A. V. (2017) Managing the load schedule of the administrative building taking into account emerging risks when connecting the kinetic energy storage to the power supply system, Electrical Engineering \& Electromechanics, 6, p.69-73.

[2] Chen, H., Cong, T.N., Yang, W., Tan, C., Li, Y., Ding, Y. (2009) Progress in electrical energy storage system: A critical review , Prog. Nat. Sci., 19, p.291-312.

[3] Tawfiq, M. Aljohani, (2014) The Flywheel Energy Storage System: A Conceptual Study, Design, and Applications in Modern Power Systems, International Journal of Electrical Energy, 2(2), p. 146-153.

[4] Savchenko, N. A., Tretjak, A. V. (2019) Autonomous uninterrupted electrical supply system with hybrid energy storages for low-current consumers, Scientific notes of Taurida National V.I. Vernadsky University. Series: Technical Sciences, 30(69), p. 20-24.

[5] Kravets, V.A., Savchenko, N.A., Tretjak, A. V. (2019) Improving the environmental friendliness of energy storage systems when using kinetic energy storage devices as storage devices, Ecological Sciences, 3(26), p.143-146.

[6] Alekseev, B.A. (2005) The use of energy storage in the electric power industry, Electro. electrical engineering, electric power industry, electrical industry, 1, p. 42-46.

[7] Kireeva, E.A., Tsyruk, S.A. (2005) Power supply for residential and public buildings. Moscow: NTF Energoprogress. $96 \mathrm{p}$.

[8] Gamazin, S.I., Kudrin, B.I., Tsyruk, S.A. (2010) Handbook of energy supply and electrical equipment of industrial enterprises and public buildings. Moscow: MEI Publishing House. 745 p.

[9] Mankov, V.D. (2010) Basics of designing power supply systems. Reference manual. SPb: NOU DPO "UMITC" Electro Service. $664 \mathrm{p}$.

[10] Dobrego, K.V. (2017) Monte Carlo model of the electrical load of a housing and communal facility for the study of generator-drive-consumer systems, Science and technology, 16(2), p.160-170.

[11] Pavlov, A.V. (2014) Calculation of electrical loads of office buildings, In: Modern energy systems and complexes and their management: materials of the XII Intern. scientific and practical Conference, Novocherkassk: YRSPU, p.67-72.

[12] Taranov, D.Yu., Pavlov, A.V., Nadtoka, I.I. (2015) Analysis of the random component of the daily graphs of the electrical load of apartment buildings", In: Modern energy systems and complexes and their management: materials of the XIII Intern. scientific and practical Conference, Novocherkassk: YRSPU, p.42-48.

[13] Andronov, A.M., Kopytov, E.A.,. Gringlaz, L.Ya.(2004) Probability Theory and Mathematical Statistics. St. Petersburg: Peter. $461 \mathrm{p}$.

\section{СПИСОК ЛІТЕРАТУРИ}

[1] Shevchenko, S. Yu., Savchenko, N. A., Tretjak, A. V. (2017) Managing the load schedule of the administrative building taking into account emerging risks when connecting the kinetic energy storage to the power supply system, Electrical Engineering \& Electromechanics, 6, p.69-73.

[2] Chen, H., Cong, T.N., Yang, W., Tan, C., Li, Y., Ding, Y. (2009) Progress in electrical energy storage system: A critical review, Prog. Nat. Sci., 19, p.291-312.

[3] Tawfiq, M. Aljohani, (2014) The Flywheel Energy Storage System: A Conceptual Study, Design, and Applications in Modern Power Systems, International Journal of Electrical Energy, 2(2), p. 146-153.

[4] Савченко, N. А., Трет’як, А. V. (2019) Системи автономного безперебійного електропостачання 3 гібридними накопичувачами енергії для малопотужних споживачів, Вчені записки Таврійського національного університету імені В.І. Вернадського. Серія: Технічні науки», 30(69), с. 20-24.

[5] Кравець, В.А., Савченко, Н.П., Трет'як, А. В. (2019) Підвищення екологічності систем накопичення енергії при використанні кінетичних енергонакопичувачів у якості акумулюючих пристроїв, Екологігні науки, 3(26), c. 143-146.

[6] Алексеев, Б.А. (2005) Применение накопителей энергии в электроэнергетике, Электро. электротехника, электроэнергетика, электротехническая промышленность, 1, с. $42-46$.

[7] Киреева, Э.А., Цырук, S.А. (2005) Электроснабжение жилых и общественных зданий. Москва: НТФ «Энергопрогресс». $96 \mathrm{c}$.

[8] Гамазин, С.И., Кудрин, Б.И., Цырук, С.А. (2010) Справочник по энергоснабжению и электрооборудованию промышленных предприятий и общественных зданий. Москва: Издательский дом МЭИ. $745 \mathrm{c}$.

[9] Маньков, В.Д. (2010) Основы проектирования систем электроснабжения. Справочное пособие. СПб.: НОУ ДПО «УМИТЦ «Электро Сервис»». 664 р.

[10] Добрего, K.V. (2017) Модель электрической нагрузки жилищно-коммунального объекта для исследования систем «Генератор - накопитель - потребитель» методом Монте-Карло, Наука и техника, 16(2), c. $160-170$ 
[11] Павлов, А.В. (2014) Расчёт электрических нагрузок офисных зданий, Современные энергетические системы и комплексы и управление ими: материалы XII Междунар. науч.- практ. конф., 25 июня 2014 г., Новочеркасск : ЮРГПУ, с. 67-72.

[12] Таранов, Д.Ю., Павлов, А.В., Надтока, И.И. (2015) Анализ случайной составляющей суточных графиков электрической нагрузки многоквартирных жилых домов, Современные энергетические системы и комплексы и управление ими : материалы 13-ой Междунар. науч.-практ. конф., 25 июня 2015 г. Новочеркасск : ЮРГПУ (НПИ), с.42-48.

[13] Андронов, А.М., Копытов, Е.А.,. Гринглаз, Л.Я.(2004) Теория вероятностей и математическая статистика. СПб.: Питер. 461 с.

Надійшла до редколегії 16.04.2021

Реиензент: д.т.н. Нікіфоров А. П.

\section{Н.П.САВЧЕНКО}

Державний вищий навчальний заклад «Донецький національний технічний університет»

Вирівнювання графіка навантаження будівлі методом компенсації випадкової складової при підключенні в систему електропостачання групи кінетичних енергонакопичувачів. У статті представлені результати теоретичного дослідження процесу регулювання графіка навантаження при компенсації випадкової його складової за рахунок підключення групи кінетичних еноргонакопичувачів в систему електропостачання адміністративної будівлі. Представлені добові графіки навантажень адміністративної будівлі у вигляді адитивної моделі. Виконаний аналіз графіків навантаження реальної будівлі на основі адитивної моделі підтверджує гіпотезу про нормальний розподіл як трендової так і випадкової складової графіку електричного навантаження. Застосування даного методу аналізу для однотипних за призначенням будівель спрощує процес визначення способу регулювання навантаження і може бути автоматизований. Запропоновано подальший розвиток методу внутрішнього регулювання навантаження споживача шляхом компенсації випадкової складової графіка навантаження, що дозволяє отримати більш згладжений і більш рівномірний графік електронавантаження будівлі. Розроблено структуру моделі системи електропостачання будівлі для реалізації методу внутрішнього регулювання навантаження шляхом компенсації випадкової складової графіка навантаження. Розроблена модель описана математично, що дозволить визначити технічні параметри пристроїв, застосовуваних у структурі моделі, i алгоритм їх роботи. Застосування виконаних досліджень дозволить підвищити надійність роботи внутрішньої системи електропостачання будівлі та ефективність регулювання навантаження при незначних матеріальних витратах і високої екологічності.

Ключові слова: система електропостачання, кінетичний енергонакопичувач (КЕН), графік електричного навантаження (ГЕН), адитивна модель, метод регулювання навантаження. 